\title{
dr Paulina Szyja
}

Uniwersytet Pedagogiczny w Krakowie Katedra Ekonomii i Polityki Gospodarczej

e-mail: paulina szyja@wp.pl

\section{GOSPODARKA WODNA W SINGAPURZE}

\author{
WATER MANAGEMENT IN SINGAPORE
}

\begin{abstract}
The article takes the issue of water management in Singapore in the context of the development framework of the country. Since the beginning of independence the political authorities of the country strive related to the reversal of the negative effects of local conditions in the success. Lack of water resources has become a contribution to the development of innovation. Moreover gained knowledge and experience allows to provide abroad services in the field of environmentally sustainable practices.
\end{abstract}

Keywords: water management, water, socio-economic development, growth

JEL classification: O10, O21, O44, O53, Q25

\section{Wstęp}

Singapur to kraj, który jest dowodem na to, że posiadanie niewielkiego obszaru terytorialnego, brak zasobów energetycznych czy konieczność importu większości dóbr konsumpcyjnych nie musi oznaczać słabości i uzależnienia od innych państw. Odpowiednia polityka społeczno-gospodarcza, bazująca na stworzeniu równych szans dla wszystkich, opierająca się na podkreślaniu roli jednostki i wspólnoty, racjonalnych mechanizmach zabezpieczenia socjalnego i konkurencji wolnorynkowej wraz z publicznym interwencjonizmem oraz uwzględnieniem lokalnych uwarunkowań, może zaowocować sukcesem. Rządząca od ponad 50 lat Partia Akcji Ludowej, której przez lata przewodniczył Lee Kuan Yew, krajowe ograniczenia przekuła w sukces.

Celem artykułu jest przybliżenie zagadnienia gospodarki wodnej w kontekście kształtowania rozwoju społeczno-gospodarczego Singapuru. Metoda 
badawcza została oparta na wyborze literatury, materiałach źródłowych, a także wnioskach z wizyty studyjnej w wybranych agendach rządowych Singapuru w lutym $2016 \mathrm{r}$.

\section{Podstawy rozwoju społeczno-gospodarczego Singapuru}

Singapur, miasto-państwo Azji Południowo-Wschodniej, po uzyskaniu niepodległości w sierpniu 1965 r. stanęło przed koniecznością wyboru drogi rozwoju społeczno-gospodarczego. Było to tym bardziej trudne, że kraj charakteryzował się ogromnym zróżnicowaniem etnicznym, religijnym i kulturowym. Singapur zamieszkiwali przedstawiciele trzech bloków kulturowych: Chin, Indii i Indonezji. Byli to najczęściej robotnicy, rzemieślnicy, przedsiębiorcy. Ponadto dużo mniejszą grupę migrantów stanowili Europejczycy, którzy promowali zachodnie wzorce gospodarcze i system administracji publicznej ${ }^{1}$. Władze Singapuru położyły więc nacisk na kształtowanie singapurskiej tożsamości narodowej i podkreślenie roli wspólnoty. Warto jednak zaznaczyć, że jednocześnie wzmacniano rolę jednostki poprzez zapewnienie wszystkim jednakowych szans w zakresie dostępu do korzyści płynących z tworzenia ram rozwojowych kraju, pod warunkiem włączenia każdego obywatela w budowanie stabilności społecznej i gospodarczej.

Kolejny problem stanowiły ograniczone możliwości mieszkaniowe, a także brak infrastruktury sanitarnej.

Z kolei na płaszczyźnie gospodarczej, poza rozwiniętym portem handlowym, Singapur nie dysponował odpowiednio rozbudowanym zapleczem produkcyjnym.

Problematyczne pozostawały kwestie relacji z sąsiadami, tj. z Malezją i Indonezją. Próba zachowania autonomii w ramach tej pierwszej okazała się niepomyślna. Stosunki polityczne z obu krajami natrafiały na poważne perturbacje. Wkrótce, pod koniec 1971 r., Wielka Brytania, z powodu oszczędności, zrezygnowała z utrzymywania zaplecza militarnego w Singapurze. W rezultacie państwo musiało zorganizować własne siły obronne ${ }^{2}$.

Jednocześnie jednak cały splot okoliczności związanych z zażegnaniem konfliktu malezyjsko-indonezyjskiego z lat 1963-1966, a także wojna w Wietnamie spowodowały, że Singapur zyskał status centrum zaopatrzeniowego w regionie ${ }^{3}$.

${ }^{1}$ W. Neville, Singapore: ethnic diversity and its implication, „Annals of the Association of American Geographers" 1966, vol. 56, no. 2, s. 236.

2 C.M. Turnbull, A history of modern Singapore 1819-2005, NUS Press Singapore, Singapore 2009, s. 304-309.

3 Tamże, s. 304. 
Od roku 1965 działania władz Singapuru opierały się na programowaniu ram kształtowania wzrostu gospodarczego i jednocześnie rozwoju społecznego, z uwzględnieniem lokalnych uwarunkowań. Dlatego też Henri Ghesquiere używa sformułowania ,inżynieria dobrobytu” dla określenia sposobu programowania rozwoju społeczno-gospodarczego Singapuru ${ }^{4}$.

W okresie 1960-2000 Singapur był jedynym państwem świata, którego zagregowany średni roczny PKB kształtował się na poziomie 7-7,5\% ${ }^{5}$. Wzrost był spowodowany m.in. akumulacją związaną z tworzeniem kapitału rzeczowego, głównie za sprawą międzynarodowych koncernów. Rządząca Partia Akcji Ludowej zachęcała zagranicznych inwestorów do lokowania kapitału na miejscu, m.in. poprzez utrzymywanie niskich kosztów pracy i podatków ${ }^{6}$. Celem było pozyskiwanie nie tylko kapitału, ale również technologii i umiejętności, które pozwoliłyby na doskonalenie krajowej siły roboczej (m.in. dzięki zaangażowaniu kapitałowemu Philipsa). Dlatego też od początku władze Singapuru postawiły na wspieranie sektora produkcyjnego, w tym rafinacji ropy naftowej (inwestycje Shell, Esso). Ponadto położono nacisk na tworzenie uwarunkowań dla sektora finansowego oraz szeroko pojmowanych usług ${ }^{7}$. W ten sposób Singapur już pod koniec lat 60 . i w początkach 70 . XX w. wyraźnie wyznaczył obszary aktywności gospodarczej, które pozwoliłyby na osiągnięcie przewagi konkurencyjnej.

Wspomniane wycofanie zbrojnego zaplecza militarnego Wielkiej Brytanii, choć mogło doprowadzić do poważnych problemów gospodarczych, nie spowodowało niekorzystnych następstw. Rząd Singapuru wynegocjował pożyczkę w wysokości $50 \mathrm{mln}$ funtów, pomoc w eksploatacji systemu obrony powietrznej oraz szkolenie personelu wojskowego ${ }^{8}$. Ponadto „odzyskano” jedną dziesiątą terytorium kraju wraz z budynkami szkół, szpitali, kompleksów sportowych, a także instalacjami technicznymi, takimi jak infrastruktura stoczni marynarki. Ta ostatnia stała się podstawą dla rozwoju krajowego przemysłu stoczniowego'.

Szybki wzrost kapitału rzeczowego znalazł odzwierciedlenie w inwestycyjnych zarówno sektora prywatnego (maszyny, środki transportu, budynki zakładów produkcyjnych, kompleksy petrochemiczne), jak i publicznego (budownictwo komunalne, infrastruktura: port, lotnisko, drogi, komunikacja publiczna, system komunikacji). Było to możliwe tym bardziej, że utrzymywano

${ }^{4}$ H. Ghesquiere, Singapore's Success. Engineering economic growth, Thomson, Singapore 2007.

5 Tamże, s. 13.

${ }^{6}$ T. Targański, Singapur: fenomenalny 50-latek. Naród z musu, www.polityka.pl/tygodnikpolityka/historia/1631341,1,singapur-fenomenalny-50-latek.read (dostęp: 26.06.2016).

${ }^{7}$ C.M. Turnbull, A history of modern Singapore..., s. 302.

${ }^{8}$ M. Omar, Ch.F. Weng, British withdrawal from Singapore, singaporeinfopedia, National Library Board Singapore, http://eresources.nlb.gov.sg/infopedia/articles/SIP_1001_2009-02-10.html (dostęp: 27.06.2016).

${ }^{9}$ C.M. Turnbull, A history of modern Singapore..., s. 302, 309. 
na wysokim poziomie zarówno publiczne, jak i prywatne oszczędności ${ }^{10}$. Dzięki nim oraz bezpośrednim inwestycjom zagranicznym, począwszy od 1985 r., rozpoczęto aktywną politykę wspierania singapurskich inwestycji poza granicami kraju. W rezultacie w 1994 r. wartość bezpośrednich inwestycji Singapuru wyniosła 38 372,7 mln USD, a w 2014 r. już 619 997,2 mln USD. Obecnie największy udział w tym zakresie mają usługi finansowe i ubezpieczeniowe (51\%) oraz produkcja $(18 \%)^{11}$. Z czasem bezpośrednie inwestycje poza granicami kraju stały się wręcz koniecznością z uwagi na ograniczenia terytorialne i niemożność ulokowania zakładów produkcyjnych przez międzynarodowe koncerny. Dziś Singapurczycy rozwijają przedsiębiorstwa głównie w Malezji, Indonezji i w Chinach ${ }^{12}$. Ponadto, w oparciu o praktykę krajową, świadczą szereg usług zagranicznym partnerom, m.in. w zakresie tworzenia warunków inwestycyjnych.

Tabela 1. Podstawowe wskaźniki makroekonomiczne Singapuru w 2014 r.

\begin{tabular}{|c|c|c|c|c|c|c|c|c|}
\hline 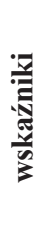 & $\begin{array}{c}\text { PKB } \\
\text { w cenach } \\
\text { rynkowych }\end{array}$ & $\begin{array}{c}\text { Roczny } \\
\text { wzrost } \\
\text { pkb } \\
\text { w } \%\end{array}$ & $\begin{array}{c}\text { Poziom } \\
\text { inflacji } \\
\text { (deflator } \\
\text { pkb } \\
\text { (rocznie } \\
\text { w \%) }\end{array}$ & $\begin{array}{c}\text { Rolnictwo, } \\
\text { wartość } \\
\text { dodana } \\
(\% \text { pkb) }\end{array}$ & $\begin{array}{c}\text { Przemysl, } \\
\text { wartość } \\
\text { dodana } \\
(\% \text { pkb) }\end{array}$ & $\begin{array}{c}\text { Usługi, } \\
\text { wartość } \\
\text { dodana } \\
\text { (\% pkb) }\end{array}$ & $\begin{array}{c}\text { Eksport } \\
\text { towarów } \\
\text { i usług } \\
\text { (\% pkb) }\end{array}$ & $\begin{array}{c}\text { Import } \\
\text { towarów } \\
\text { i usług } \\
\text { (\% pkb) }\end{array}$ \\
\hline 芯 & $\begin{array}{c}307,9 \text { mld } \\
\text { USD }\end{array}$ & 2,9 & 0,2 & 0 & 24,9 & 75 & 187,6 & 163,2 \\
\hline
\end{tabular}

Źródło: World Bank, http://databank.worldbank.org/ (dostęp 24.06.2016).

Sukces tego niewielkiego - bo liczącego niespełna $720 \mathrm{~km}^{2}$ powierzchni i 5,6 mln mieszkańców - kraju jest tym bardziej godny podziwu, że wyrastając z małej wioski rybackiej, będąc następnie kolonią brytyjską, dziś jest jednym z najważniejszych ośrodków handlu morskiego na świecie (tabela 1). Jest drugim co do wielkości, po Szanghaju, portem przeładunkowym (w 2014 r. liczba jednostek ładunkowych wyniosła $33,87 \mathrm{mld}^{\mathrm{TEU}}{ }^{13}$ ). Jest też centrum biznesowym. Działa tutaj ponad 1200 instytucji finansowych, a wśród nich 5 banków lokalnych, 120 banków zagranicznych (np. Bank of America, Bank of China, Bank of India, Citibank, JPMorgan Chase Bank, $\mathrm{HSBC}^{14}$ ), holdingi finansowe, fundusze inwesty-

${ }^{10}$ H. Ghesquiere, Singapore's Success..., s. 26, 31-32.

11 Singapore's Direct Investment Abroad By Industry (End Of Period), Annual, Department of Statistics Singapore, www.tablebuilder.singstat.gov.sg/publicfacing/createDataTable. action?refId=5667 (dostęp: 28.06.2016).

12 Tamże.

13 TOP 50 WORLD CONTAINER PORTS, World Shipping Council, www.worldshipping.org/ about-the-industry/global-trade/top-50-world-container-ports (dostęp: 24.06.2016).

${ }_{14}$ Singapore: Authorized Institutions, http://asianbanks.net/HTML/Countries/SG/SGauthinst. htm (dostęp: 26.06.2016). 
cyjne, firmy ubezpieczeniowe, brokerskie ${ }^{15}$. Dużym atutem było włączenie się Singapuru w mechanizm świadczenia międzynarodowych usług finansowych w ten sposób, że może on funkcjonować przez 24 godziny na dobę ${ }^{16}$.

Jednocześnie PAL od początku prowadziła zrównoważoną politykę społeczną, tym bardziej wymagającą, że początki niezależności Singapuru były charakteryzowane przez bezrobocie, ograniczenia mieszkaniowe czy niski poziom wykształcenia ${ }^{17}$. Tymczasem w 2014 r. stopa bezrobocia była na poziomie $1,9 \%{ }^{18}$. W celu poprawy warunków lokalowych powołano (już w roku 1960) Radę Mieszkań i Rozwoju (Housing and Development Board), która obecnie zarządza $1 \mathrm{mln}$ mieszkań zajmowanych przez $80 \%$ populacji Singapuru ${ }^{19}$. Podobnie korzystne rezultaty udało się osiągnąć na płaszczyźnie edukacji. Narodowy Uniwersytet Singapuru (National University of Singapore) w rankingu uczelni za okres 2015/2016 uplasował się na 12. miejscu. Poza NUS, w kraju funkcjonuje pięć innych publicznych uczelni oraz spora liczba prywatnych. Największa liczba studentów kończy studia inżynierskie ${ }^{20}$.

Warto również podkreślić rolę zagadnień powiązanych ze środowiskiem naturalnym w polityce społecznej i gospodarczej władz Singapuru. Wspomniany Henri Ghesquiere pisze wręcz o „wzroście zrównoważonym ekologicznie”21. Wzrost ten jest konsekwencją konieczności odwrócenia negatywnych uwarunkowań związanych z:

- ograniczonym zakresem terytorialnym,

- dużą gęstością zaludnienia (ponad 7700 osób na 1 km²),

- brakiem zasobów wody,

- zanieczyszczeniem powietrza.

Mała przestrzeń wymusza zmiany w planowaniu przestrzennym. W Singapurze dba się o każdy element terenu. Obok wielkich wieżowców centrum finansowego, obiektów mieszkalnych, zakładów produkcyjnych, rozwiązań infrastrukturalnych, w mieście są także widoczne tereny zielone. Najbardziej znane to Ogrody Botaniczne (the Botanic Gardens) i Ogrody nad Zatoką (Gardens by the Bay), które łącznie zajmują obszar 183 ha (zdjęcie 1).

${ }^{15}$ Monetary Authority of Singapore, Number of Financial Institutions and Relevant Organisations in Singapore, https://masnetsvc.mas.gov.sg/FID.html (dostęp: 26.06.2016).

${ }^{16}$ H. Ghesquiere, Singapore's Success..., s. 47.

17 Tamże, s. 46.

18 Singapore Unemployment Rate 1986-2016, www.tradingeconomics.com/singapore/unemployment-rate (dostęp: 28.06.2016).

19 Housing and Development Board, www.hdb.gov.sg/cs/infoweb/about-us (dostęp: 28.06.2016).

${ }^{20}$ Ministry of Education Singapore, Education Statistics Digests 2015, Singapore 2015, s. $18-21$.

${ }^{21}$ H. Ghesquiere, Singapore's Success... 


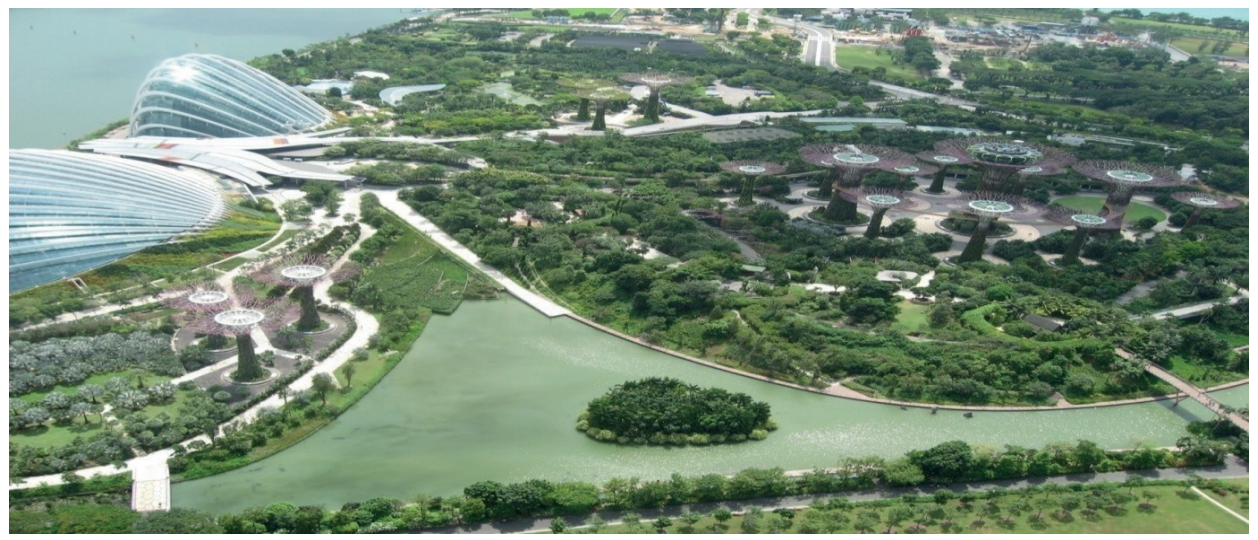

Zdjęcie 1. Gardens by the Bay

Źródło: archiwum własne.

Poza tym kładzie się ogromy nacisk na rozwój zielonej infrastruktury w postaci zazieleniania dachów, a także tarasów budynków mieszkalnych. Taka organizacja przestrzeni wynika z następujących powodów: możliwości wykorzystania naturalnych sposobów chłodzenia pomieszczeń w warunkach tropikalnych, ochrony przed wysokim promieniowaniem UV, funkcji estetycznych (zdjęcie 2).

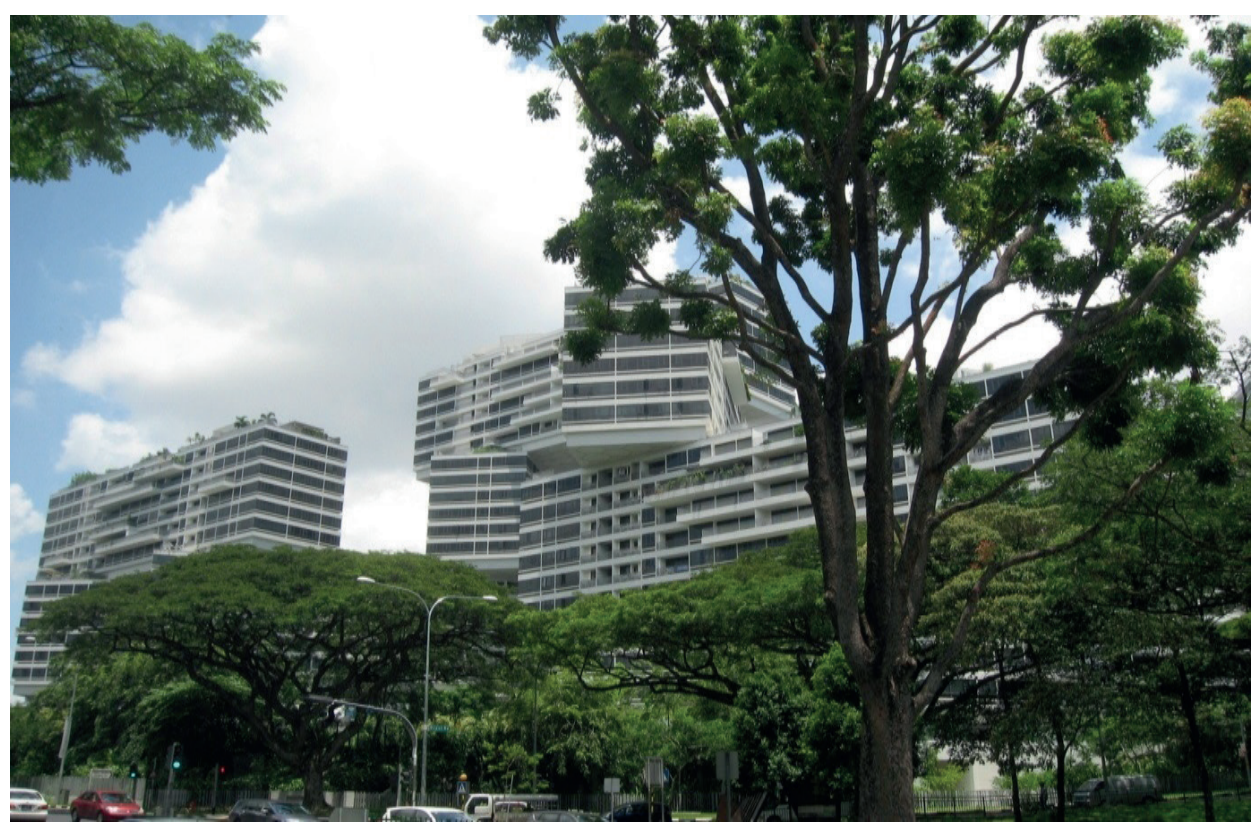

Zdjęcie 2. Przykład zielonej infrastruktury w budownictwie mieszkalnym Singapuru

Źródło: archiwum własne. 
Problem ograniczonej przestrzeni napotyka kolejny - związany z gęstym zaludnieniem kraju. W celu przezwyciężenia tych trudności buduje się wysokie obiekty oraz modernizuje stare w taki sposób, aby były nie tylko funkcjonalne, ale również efektywne w zakresie wykorzystania energii. Rządowa agencja Building and Construction Authority przeprowadziła modernizację jednego z budynków w ten sposób, że jest samowystarczalny pod względem energetycznym (Zero Energy Building). Co ciekawe, jest on wyposażony w odnawialne źródła energii (panele słoneczne), które produkują więcej energii niż obiekt faktycznie zużywa (zdjęcia 3,4). Obecnie trwają prace związane z zakończeniem budowy nowego zeroenergetycznego budynku agencji.

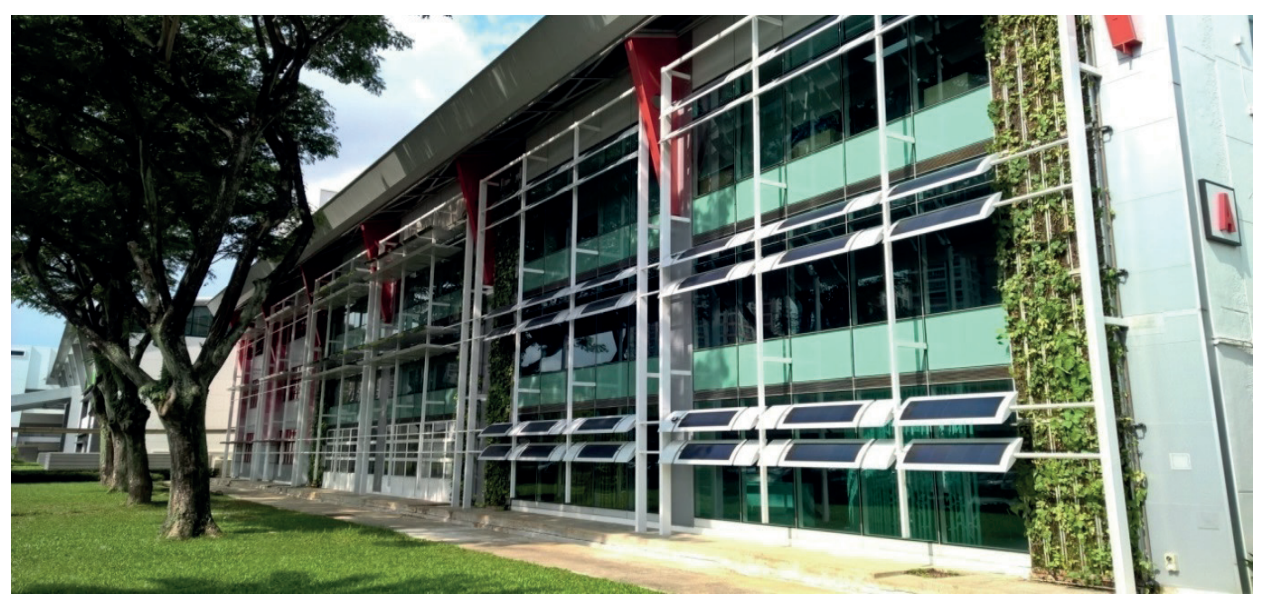

Zdjęcie 3. Zero Energy Building agencji Building and Construction Authority Źródto: archiwum własne.

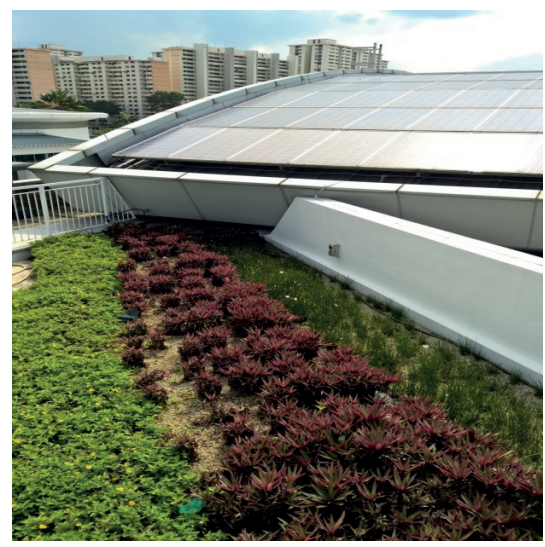

Zdjęcie 4. Dach zeroenergetycznego budynku agencji Building and Construction Authority Źródto: archiwum własne. 
Z kolei zanieczyszczenie powietrza jest powodowane m.in. poprzez skutki produkcji oleju palmowego w Malezji ${ }^{22}$. Wylesianie i palenie lasów deszczowych oraz torfowisk, związane z zagospodarowaniem terenów pod uprawę tej rośliny, powoduje emisję dwutlenku węgla.

Zagadnienie braków zasobów wodnych w Singapurze zostanie omówione w osobnym rozdziale.

\section{Polityka ekologiczna Singapuru}

Działania władz Singapuru w zakresie ochrony środowiska naturalnego są ściśle powiązane z koncepcją zrównoważonego i trwałego rozwoju. Dowodem na to mogą być nie tylko cytowane słowa Ghesquiere'a czy dane statystyczne potwierdzające, iż w okresie 2004-2014 w Singapurze średnia liczba dni z jakością powietrza na poziomie dobrym i umiarkowanym wyniosła aż $98 \%{ }^{23}$. Według rankingu najbardziej przyjaznych miast świata pod względem warunków i jakości życia przygotowanego przez Mercer's Quality of Living 26. miejsce zajmuje Singapur ${ }^{24}$.

Jak podkreśla Tan Young Soon, singapurskie podejście do zarządzania środowiskiem opiera się na pięciu filarach, identyfikowanych z pięcioma $\mathrm{E}$, tj. od pierwszej litery angielskich słów: Engineering (projektowanie), Economics (gospodarka), Education (edukacja), Enforcement (egzekwowanie), Engagement (zaangażowanie). Pierwszy odnosi się do rozwoju infrastruktury sanitarnej, przeciwpowodziowej, produkcji wody, recyklingu śmieci. Drugi dotyczy efektywności środowiskowej w procesach produkcyjnych i usługowych. Edukacja jest związana z mobilizowaniem ludzi do zmiany ich przyzwyczajeń, a także uświadomienia konsekwencji negatywnych praktyk dla środowiska i człowieka. Stąd też konieczność egzekwowania przepisów prawnych związanych np. z zaśmiecaniem przestrzeni publicznej ${ }^{25}$. I wreszcie społeczeństwo musi być świadome swej odpowiedzialności za środowisko naturalne.

Władze Singapuru od początku niezależności kraju identyfikowały kwestie rozwoju gospodarczego z jakością środowiska naturalnego. Co więcej,

${ }^{22}$ L.K. Goodman, K. Mulik, Clearing the air: Palm Oil, Peat Destruction, and Air Pollution, The Union of Concerned Scientists, 2015, www.ucsusa.org/sites/default/files/attach/2015/03/ clearing-the-air-ucs-2015.pdf (dostęp: 28.06.2016)

${ }^{23}$ Ministry of the Environment and Water Resources, Key Environmental Statistics 2015, s. 3.

${ }^{24}$ WESTERN EUROPEAN CITIES TOP QUALITY OF LIVING RANKING - MERCER, London 2016, www.mercer.com/newsroom/western-european-cities-top-quality-of-living-ranking-mercer.html (dostęp: 28.06.2016).

${ }^{25} \mathrm{Na}$ singapurskich ulicach trudno dostrzec kosze na śmieci, mimo to jest tam bardzo czysto. Na stacjach metra nie można spożywać napojów i jedzenia. Nieprzestrzeganie wymienionych praktyk jest karane finansowo. 
podkreślano, że troska o to ostatnie zachęca do inwestycji i rozwija talenty, które przekładają się na dalszy wzrost gospodarczy ${ }^{26}$. W tym zakresie propagowano ideę „miasta-ogrodu” (ang. garden city). W rezultacie z miasta o ograniczonej infrastrukturze sanitarnej, brudnych i wąskich drogach, ze strumieniami oraz rzekami pełniącymi funkcje otwartych systemów kanalizacyjnych dla prywatnych domów i zakładów przekształciło się w „zielone miasto”27.

W 1992 r. wprowadzono pierwszy Singapurski Zielony Plan (Singapore Green Plan). Kolejna wersja dokumentu z 2002 r. podkreślała konieczność nie tylko dbałości o jakość środowiska naturalnego, ale przede wszystkim zoperacjonalizowanie zasady zrównoważonego i trwałego rozwoju. Wyznaczono wówczas dziesięć obszarów priorytetowych ${ }^{28}$, w tym: gospodarka odpadami, ochrona przyrody, czyste powietrze, gospodarka wodna, zdrowie publiczne, partnerstwo społeczne, współpraca międzynarodowa, innowacje. Obecnie polityka Singapuru w omawianym zakresie opiera się na pięciu filarach (rysunek 1).

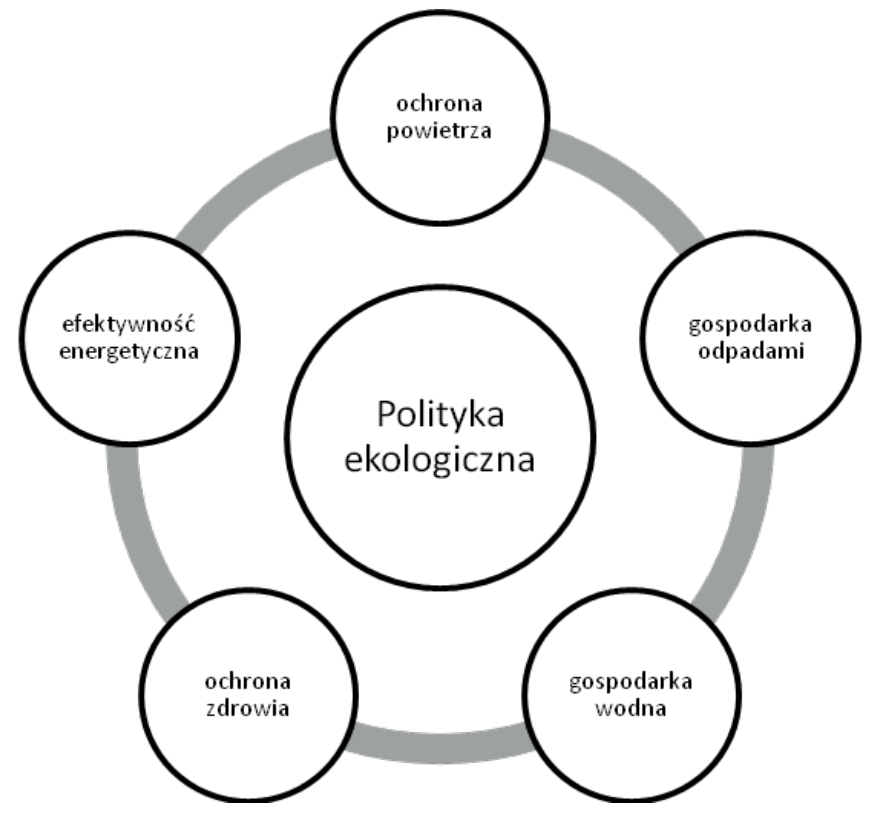

Rysunek 1. Filary polityki ekologicznej Singapuru

Źródło: opracowanie własne na podstawie: Ministry of the Environment and Water Resources, http://www.mewr.gov.sg/learn-the-issue (dostęp 25.06.2016).

${ }^{26}$ T. Yong Soon, L. Tung Jean, K. Tan, Clean, Green and Blue. Singapore's Journey Towards Environmental and Water Sustainability, Institute of Southeast Asian Studies, Singapore 2009, s. xxiv, 4.

${ }^{27}$ Ministry of the Environment, The Singapore Green Plan 2012. Beyond clean and Green, Towards Environmental Sustainability, Singapore 2002, s. 1.

${ }^{28}$ Tamże, s. x. 
W każdym z filarów wyznaczono cele szczegółowe, przykładowo ${ }^{29}$ :

1. Ochrona powietrza:- obniżyć roczny poziom drobnego pyłu zawieszonego (PM 2.5) do poziomu $12 \mu \mathrm{g} / \mathrm{m}^{3} \mathrm{w} 2020 \mathrm{r}$. i utrzymanie przez kolejną dekadę.

2. Gospodarka odpadami: zwiększyć poziom całkowitego recyklingu do poziomu $70 \% \mathrm{w} 2030 \mathrm{r}$.

3. Gospodarka wodna: zmniejszyć dzienne zużycie wody na mieszkańca do $1471 \mathrm{w} 2020$ i $140 \mathrm{w} 2030 \mathrm{r}$.

4. Ochrona zdrowia publicznego: uczynić z Singapuru wiodącego w regionie ośrodka epidemiologicznego.

5. Efektywność energetyczna: zmniejszyć poziom zużycia energii.

Ponadto w 2014 r. ogłoszono Zrównoważony Plan Singapuru 2015 (Sustainable Singapore Blueprint) podkreślający konieczność działań w następujących obszarach: zielone i niebieskie przestrzenie, mobilność, zrównoważone wykorzystanie zasobów, jakość powietrza, zabezpieczenie obszarów zalewowych, zarządzanie społeczne. Tym samym dla każdego z priorytetów wyznaczono cele do $2030 \mathrm{r}$. (tabela 2).

Tabela 2. Obszary i cele Zrównoważonego Planu Singapuru 2015

\begin{tabular}{|c|c|c|c|}
\hline Priorytet & Cel szczególowy & Stan obecny & Cel do 2030 r. \\
\hline 1 & 2 & 3 & 4 \\
\hline \multirow{5}{*}{$\begin{array}{l}\text { tereny zielone } \\
\text { i obszary wodne }\end{array}$} & zielone tarasy & 61 ha & 200 ha \\
\hline & $\begin{array}{l}\text { 1) parki i obszary wodne } \\
\text { z przeznaczeniem rekreacyjnym } \\
\text { a) parki } \\
\text { b) obszary wodne }\end{array}$ & $\begin{array}{l}1040 \text { ha } \\
959 \text { ha }\end{array}$ & $\begin{array}{l}0,8 \mathrm{ha} / 1000 \text { osób } \\
1039 \text { ha }\end{array}$ \\
\hline & $\begin{array}{l}\text { 2) długość łączników parkowych } \\
\text { i śródlądowe rzek z przeznaczeniem } \\
\text { rekreacyjnym } \\
\text { a) łączniki parkowe } \\
\text { b) śródlądowe rzek }\end{array}$ & $\begin{array}{l}216 \mathrm{~km} \\
93 \mathrm{~km}\end{array}$ & $\begin{array}{l}400 \mathrm{~km} \\
100 \mathrm{~km}\end{array}$ \\
\hline & 3) długość ścieżek przyrodniczych & $21 \mathrm{~km}$ & $180 \mathrm{~km}$ \\
\hline & $\begin{array}{l}\text { 4) udział procentowy gospodarstw } \\
\text { domowych z możliwością dostępu } \\
\text { do parków w odległości } 10 \text { min. } \\
\text { spaceru }\end{array}$ & $80 \%$ & $90 \%$ \\
\hline
\end{tabular}

${ }^{29}$ Ministry of the Environment and Water Resources, www.mewr.gov.sg/learn-the-issue(dostęp 25.06.2016). 


\begin{tabular}{|c|c|c|c|}
\hline 1 & 2 & 3 & 4 \\
\hline \multirow[t]{4}{*}{ mobilność } & 1)długość ścieżek rowerowych & $230 \mathrm{~km}$ & $700 \mathrm{~km}$ \\
\hline & $\begin{array}{l}\text { 2) udział modalnego modelu podróży } \\
\text { komunikacją miejską w godzinach } \\
\text { szczytu }\end{array}$ & $64 \%$ & $75 \%$ \\
\hline & 3) długość linii kolejowej & $180 \mathrm{~km}$ & $360 \mathrm{~km}$ \\
\hline & $\begin{array}{l}\text { 4) udział procentowy gospodarstw } \\
\text { domowych z możliwością dostępu } \\
\text { do parków w odległości } 10 \text { min. } \\
\text { od stacji kolejowej }\end{array}$ & $58,5 \%$ & $80 \%$ \\
\hline \multirow[t]{4}{*}{$\begin{array}{l}\text { zrównoważone } \\
\text { wykorzystanie } \\
\text { zasobów }\end{array}$} & $\begin{array}{l}\text { 1) udział procentowy budynków } \\
\text { z certyfikatem BCA Green Mark } \\
\text { Certiefied }\end{array}$ & $21,9 \%$ & $80 \%$ \\
\hline & 2) poprawa efektywności energetycznej & $22 \%(2012$ r. $)$ & $35 \%$ \\
\hline & $\begin{array}{l}\text { 3) konsumpcja krajowych zasobów } \\
\text { wodnych - dzienna na osobę }\end{array}$ & 1511 & 1471 \\
\hline & $\begin{array}{l}\text { 4) narodowa stopa recyklingu } \\
\text { a) krajowa stopa recyklingu } \\
\text { b) niekrajowa stopa recyklingu }\end{array}$ & $\begin{array}{l}61 \% \\
20 \% \\
77 \%\end{array}$ & $\begin{array}{l}70 \% \\
30 \% \\
81 \%\end{array}$ \\
\hline \multirow{6}{*}{$\begin{array}{l}\text { jakość powietrza } \\
\text { (cele do } 2020 \mathrm{r} \text {.) }\end{array}$} & 1) PM 2,5 (rocznie) & $20 \mu \mathrm{g} / \mathrm{m}^{3}$ & $12 \mu \mathrm{g} / \mathrm{m}^{3}$ \\
\hline & 2)PM 10 (rocznie) & $31 \mu \mathrm{g} / \mathrm{m}^{3}$ & $20 \mu \mathrm{g} / \mathrm{m}^{3}$ \\
\hline & 3) dwutlenek siarki (w ciągu 24 h) & $75 \mu \mathrm{g} / \mathrm{m}^{3}$ & $50 \mu \mathrm{g} / \mathrm{m}^{3}$ \\
\hline & 4) ozon (8 h) & $139 \mu \mathrm{g} / \mathrm{m}^{3}$ & $100 \mu \mathrm{g} / \mathrm{m}^{3}$ \\
\hline & 5) dwutlenek azotu (rocznie) & $25 \mu \mathrm{g} / \mathrm{m}^{3}$ & $40 \mu \mathrm{g} / \mathrm{m}^{3}$ \\
\hline & 6) tlenek węgla ( $8 \mathrm{~h}$ ) & $5,5 \mathrm{mg} / \mathrm{m}^{3}$ & $10 \mathrm{mg} / \mathrm{m}^{3}$ \\
\hline tereny zalewowe & $\begin{array}{l}\text { 1) zmniejszenie obszaru terenów } \\
\text { zalewowych }\end{array}$ & 36 ha & 23 ha \\
\hline \multirow[t]{3}{*}{$\begin{array}{l}\text { zarządzanie } \\
\text { społeczne }\end{array}$} & $\begin{array}{l}\text { 1) liczba wolontariuszy } \\
\text { zaangażowanych na rzecz } \\
\text { zazielenienia miasta }\end{array}$ & $>1000$ & 5000 \\
\hline & $\begin{array}{l}\text { 2) liczba wspólnot Kwitnących } \\
\text { Ogrodów }\end{array}$ & $>700$ & 2000 \\
\hline & $\begin{array}{l}\text { 3) zwiększenie liczby obszarów } \\
\text { szczególnie podatnych } \\
\text { na zaśmiecenie }\end{array}$ & $>300$ & 500 \\
\hline
\end{tabular}

Źródto: Ministry of the Environment and Water Resources, Ministry of National Development, Our Home, Our Environment, Our Future, Sustainable Singapore Blueprint 2015, Singapore 2014, s. 109. 
Zakładane cele są bardzo ambitne. Warto jednak zwrócić uwagę na kilka kwestii. Po pierwsze, Zrównoważony Plan Singapuru został opracowany przez dwa resorty, tj. Ministerstwo Środowiska i Zasobów Wodnych oraz Ministerstwo Rozwoju Narodowego. Wyraźnie zatem kwestie troski o jakość środowiska narodowego są powiązane z rozwojem społeczno-gospodarczym, tym bardziej że w omawianym dokumencie podkreśla się również rolę „zazielenienia biznesu"30. Po drugie, mimo ograniczonenego obszaru i znacznej populacji, władze mają zamiar zwiększyć obszar terenów zielonych. Ponadto kładzie się ogromny nacisk na rozwój komunikacji publicznej. Jest to tym bardziej warte naśladowania, że w Singapurze działa obecnie pięć linii metra. Kolejna uwaga dotyczy zaangażowania obywateli w troskę o obszary zielone i rozwijanie inicjatyw, takich jak „Kwitnące ogrody”, co mobilizuje mieszkańców do zazieleniania osiedli mieszkaniowych.

Tabela 3. Energia i środowisko w Singapurze w 2013 r.

\begin{tabular}{|c|c|c|c|c|c|c|}
\hline 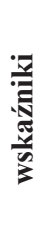 & $\begin{array}{c}\text { Emisja co }_{2} \\
\text { na jednostkę } \\
\text { pkb } \\
\text { (kg co } / 2005_{2} \\
\text { usd)* }\end{array}$ & $\begin{array}{l}\text { Lączna } \\
\text { produkcja } \\
\text { energii } \\
\text { (gwh) }\end{array}$ & $\begin{array}{c}\text { Całkowite } \\
\text { zużycie energii } \\
\text { (gwh) }\end{array}$ & $\begin{array}{c}\text { Rodukcja } \\
\text { odpadów } \\
\text { - mln ton/ } \\
\text { rok** }\end{array}$ & $\begin{array}{l}\text { Calkowity } \\
\text { recykling } \\
\text { odpadów } \\
\text { - mln ton/ } \\
\text { rok }(\%)^{* *}\end{array}$ & $\begin{array}{c}\text { Liczba } \\
\text { zielonych } \\
\text { samochodów } \\
\text { (green } \\
\text { vehicles) } \\
\text { (liczba sztuk) }\end{array}$ \\
\hline 芯 & 0,23 & $\begin{array}{c}47964 \mathrm{GWh}^{*} \\
\text { (w tym udział } \\
\text { poszczególnych } \\
\text { źródeł energii: } \\
\text { węgiel } 391 \mathrm{GWh} \text {, } \\
\text { ropa naftowa } \\
2329 \mathrm{GWh} \text {, } \\
\text { gaz } 43871 \mathrm{GWh} \text {, } \\
\text { biopaliwa } \\
93 \mathrm{GWh} \text {, odpady } \\
1264 \mathrm{GWh} \text {, solar } \\
\text { PV } 16 \mathrm{GWh} \text { ) }\end{array}$ & $\begin{array}{c}45808 \mathrm{GWh} * \\
\text { (w tym: } \\
\text { przemysł } \\
18641 \mathrm{GWh}, \\
\text { transport } \\
2370 \mathrm{GWh}, \\
\text { budownictwo } \\
6766 \mathrm{GWh}, \\
\text { prywatne i pu- } \\
\text { bliczne usługi } \\
17680 \mathrm{GWh}, \\
\text { inne } 351 \mathrm{GWh} \text { ) }\end{array}$ & 7,85 & $\begin{array}{c}4,83 \\
(61 \%)\end{array}$ & 11,635 \\
\hline
\end{tabular}

* IEA, Singapore: Indicators for 2013, www.iea.org/statistics/statisticssearch/report/?country=S ingapore\&product=indicators (dostęp: 25.06.2016).

** Ministry of the Environment and Water Resources, Key Environmental Statistics 2015, s. 4.

Plany w zakresie zrównoważonego rozwoju Singapuru warto odnieść do dotychczasowych osiągnięć w zakresie emisji dwutlenku węgla, produkcji i konsumpcji energii, recyklingu odpadów i udziału pojazdów ekologicznych w całkowitej liczbie samochodów użytkowanych w tym kraju. Analiza danych

${ }^{30}$ Por. P. Szyja, Rola rozwiąań przyjaznych dla środowiska naturalnego w procesach restrukturyzacji przemystu, Warszawa-Kraków 2014, s. 219-235, Prace Komisji Geografii Przemystu Polskiego Towarzystwa Geograficznego, nr 27: Wpływ kryzysu gospodarczego na przemiany struktur przemystowych. 
statystycznych za 2013 r. wyraźnie wskazuje m.in. na niski poziom emisji dwutlenku węgla, wysoki udział recyklingu odpadów, niższe całkowite zużycie energii niż poziom produkcja (tabela 3 ).

Z kolei liczba samochodów ekologicznych na tle całkowitej liczby pojazdów, tj. 974170 w 2013 r. jest stosunkowo niewielka ${ }^{31}$. Jednakże władze ograniczają liczbę samochodów osobowych poprzez wysokie cło oraz opłaty za poruszanie się w godzinach szczytu. Być może jest to również fakt tłumaczący powody nieuwzględnienia tego rodzaju mobilnych rozwiązań w Zrównoważonym Planie Singapuru.

Warto podkreślić, że działania w zakresie zrównoważonego rozwoju są propagowane poza granicami kraju. Przykładowo eksperci rządowej agencji zajmującej się zrównoważonym budownictwem (Building and Construction Authority) doradzają przy projekcie chińskiego ekologicznego miasta Tianjin. W ten sposób Singapur świadczy usługi, bazując na najlepszych krajowych doświadczeniach. Naukowcy i eksperci tego państwa przekonują, że można osiągnąć sukces gospodarczy, kierując się troską o środowisko naturalne.

\section{Zasoby wody - czynnik kształtowania bezpieczeństwa ekologicznego}

Zagadnienie zasobów wodnych, ze względu na ich brak, było od zawsze w centrum zainteresowania władz Singapuru. Dlatego też przeciwdziałanie niekorzystnym uwarunkowaniom w tym zakresie było i jest jednym z głównych obszarów działań nie tylko w kwestii polityki ekologicznej, gospodarczej, ale także zapewnienia bezpieczeństwa ekologicznego kraju (rysunek 2).

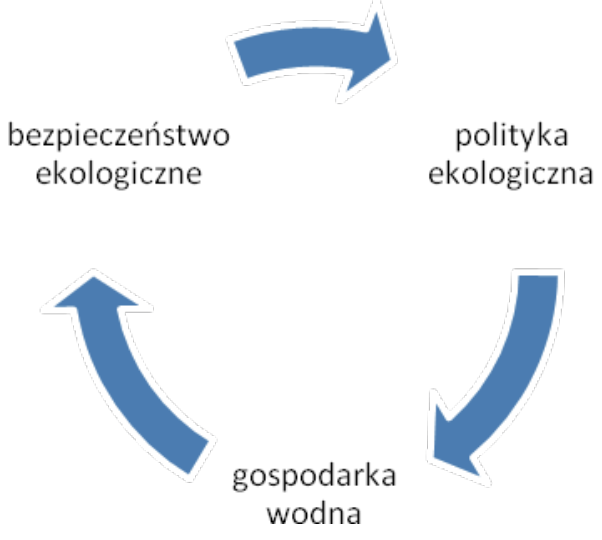

Rysunek 2.

Źródto: opracowanie własne.

${ }^{31}$ Land Transport Statistics in brief 2014, www.lta.gov.sg/content/dam/ltaweb/corp/PublicationsResearch/files/FactsandFigures/Statistics\%20in\%20Brief\%202014.pdf (dostęp: 29.06.2016). 
O znaczeniu wody jako czynnika kształtowania bezpieczeństwa narodowego świadczy m.in. ustanowienie Ministerstwa Środowiska i Zasobów Wodnych.

Do niedawna problemy z wodą w Singapurze były związane przede wszystkim z brakiem zasobów własnych, małym obszarem terytorialnym, który uniemożliwiał magazynowanie wody deszczowej, a także silnym odparowywaniem. Wszystkie te czynniki sprawiały, że konieczny był import. Przez długi okres Singapur był uzależniony od dostaw wody z malezyjskiego stanu Johor. Dziś praktyki w tym zakresie mają mniejszy wymiar z uwagi na próby politycznych nacisków Malezji na Singapur z użyciem wody jako karty przetargowej i wzrastającą niezależność tego ostatniego w zakresie dywersyfikacji źródeł zasobów wodnych.

Dzięki kompleksowemu planowaniu i zarządzani, państwo jest obecnie w stanie samodzielnie zaspokoić potrzeby w zakresie dostępu do wody na poziomie ponad $50 \%{ }^{32}$. Co więcej, wydatki związane z rozbudową infrastruktury sanitarnej, wodnej nie tylko przyczyniają się do polepszenia jakości życia mieszkańców, lepszych warunków prowadzenia działalności gospodarczej, ale również sprzyjają tworzeniu nowych miejsc pracy ${ }^{33}$.

Pierwsze kroki w kierunku rozwijania gospodarki wodnej w Singapurze zostały poczynione już w roku 1963, kiedy powołano Radę Użyteczności Publicznej (Public Utilities Board), która miała zająć się infrastrukturą zapewniającą mieszkańcom dostęp do wody, elektryczności i gazu. Z czasem dookreślono jej nazwę: Narodowa Agencja Singapuru ds. Wody (Singapore's National Water Agency), a działania skoncentrowano na budowie lokalnych zbiorników wodnych. W 1972 r. przyjęto pierwszy Plan Zagospodarowania Wody (Water Master Plan), który zawierał projekty dotyczące wykorzystania wody z krajowych zbiorników oraz oczyszczania i odsalania wody. Z kolei w 1983 r. wdrożono Plan Wychwytywania Wody (Water Catchment Policy), którego celem było stworzenie infrastruktury umożliwiającej zbieranie deszczówki ${ }^{34}$.

Obecnie szeroko pojmowana gospodarka wodna opiera się na sześciu filarach (rysunek 3).

Władze Singapuru największy nacisk kładą na powiązane działania w obszarze pozyskiwania, oczyszczania i produkcji wody. Nie szczędzą przy tym środków finansowych ze względu na potencjał innowacyjny przedsięwzięć. Według M.L. Clifforda w kraju funkcjonuje blisko 25 instytutów badawczych i laboratoriów, które łącznie przeznaczają $180 \mathrm{mln}$ USD na inicjatywy wodne ${ }^{35}$. Realizowane projekty infrastrukturalne charakteryzują się nowoczesnymi rozwiązaniami technicznymi oraz wielością funkcji. W rezultacie poczynionych prac od wczes-

${ }^{32}$ M.C. Clifford, The Greening of Asia. The Business Case for Solving Asia's Environmental Emergency, Columbia Business School Publishing, New York 2015, s. 71.

33 T. Yong Soon, L. Tung Jean, K. Tan, Clean, Green and Blue..., s. 10.

${ }^{34}$ Tamże, s. 13, 128-129.

${ }^{35}$ M.C. Clifford, The Greening of Asia ..., s. 155. 
nych lat 60. XX w. po 2014 r. udało się stworzyć w Singapurze 17 zbiorników wodnych, poprawić warunki sanitarne mieszkańców, stworzyć wodną bazę rekreacyjną (tabela 4). Przykładowo w przypadku tamy Marina Barrage połączono funkcje rekreacyjne z ochroną przeciwpowodziową oraz rezerwuarem wody.

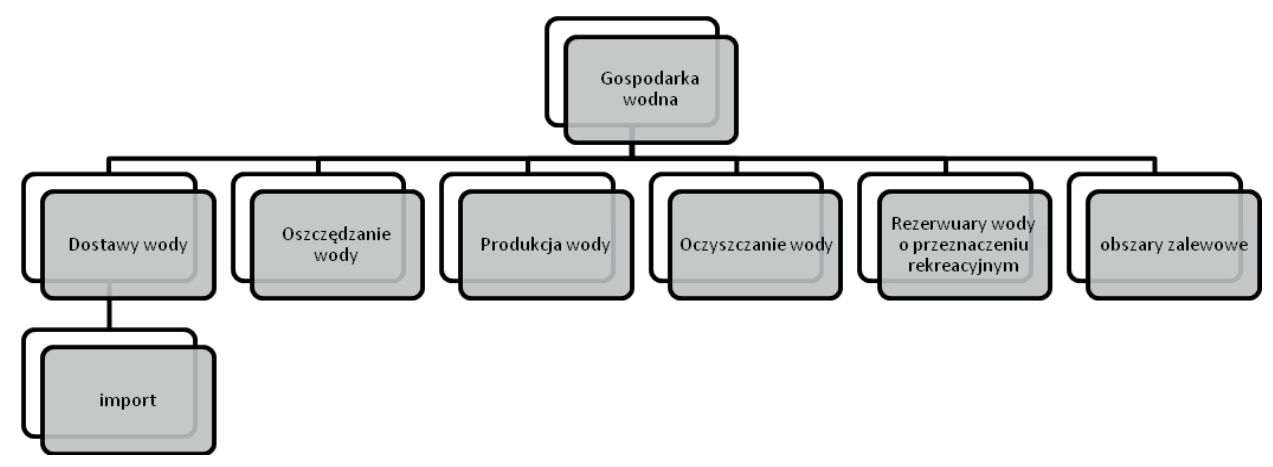

Rysunek 3.

Źrodło: opracowanie własne.

Tabela 4. Gospodarka wodna Singapuru w liczbach w 2014 r.

\begin{tabular}{|c|c|c|c|c|c|c|c|c|}
\hline 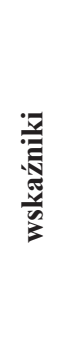 & $\begin{array}{c}\text { Oczyszcza- } \\
\text { nie zasobów } \\
\text { wodnych } \\
\text { (\% popu- } \\
\text { lacji } \\
\text { z dostępem } \\
\text { do oczysz- } \\
\text { czonych } \\
\text { zasobów } \\
\text { wodnych) }\end{array}$ & $\begin{array}{c}\text { Poprawa } \\
\text { warunków } \\
\text { sanitarnych } \\
\text { (\% po- } \\
\text { pulacji } \\
\text { z dostępem } \\
\text { do oczysz- } \\
\text { czonych } \\
\text { zasobów } \\
\text { wodnych) }\end{array}$ & $\begin{array}{c}\text { Liczba } \\
\text { zbior- } \\
\text { ników } \\
\text { wodnych } \\
\text { w singa- } \\
\text { purze }\end{array}$ & $\begin{array}{c}\text { Sprzedaż } \\
\text { wody } \\
\text { pitnej } \\
\text { ze źródel } \\
\text { krajowych } \\
\left(\mathbf{m l n} \mathbf{m}^{3}\right)\end{array}$ & $\begin{array}{c}\text { Sprzedaż } \\
\text { wody } \\
\text { pitnej } \\
\text { ze źródel } \\
\text { zagra- } \\
\text { nicznych } \\
\left(\mathbf{m l n} \mathbf{m}^{3}\right)\end{array}$ & $\begin{array}{c}\text { Sprzedaż } \\
\text { newater } \\
\left(\mathbf{m l n} \mathbf{m}^{3}\right)\end{array}$ & $\begin{array}{c}\text { Sprzedaż } \\
\text { wody } \\
\text { przemy- } \\
\text { slowej } \\
\left(\mathrm{mln} \mathrm{m}^{3}\right)\end{array}$ & $\begin{array}{c}\text { Wskaźnik } \\
\text { wyko- } \\
\text { rzystania } \\
\text { oczyszczo- } \\
\text { nej wody } \\
\left(\mathrm{mln} \mathrm{m}^{3}\right)\end{array}$ \\
\hline 苂 & 100 & 100 & 17 & 291,2 & 215,1 & 117,1 & 27,6 & 571,1 \\
\hline
\end{tabular}

Źródło: Ministry of the Environment and Water Resources, Key Environmental Statistics 2015, s. 7 .

NEWater to nazwa marki związanej z produkcją wody oczyszczonej zdatnej do spożycia. Proces wytwórczy obejmuje zaawansowaną technologię membranową oraz promieniowanie ultrafioletowe. Produkcja odbywa się w czterech fabrykach, tzw. water plants: Bedok, Kranji, Ulu Pandan, Changi. Ta ostatnia jest położona na terenie lotniska. Dodatkowo zaopatruje je w energię powstającą $\mathrm{w}$ trakcie procesu produkcji wody. $\mathrm{Z}$ kolei w Bedok znajduje się centrum 
edukacyjne NEWater Visitor Centre, w którym można zobaczyć wystawę prezentująca technologię produkcji oraz ścieżkę dydaktyczną służącą propagowaniu oszczędzania wody.

Zanim woda zostanie poddana procesom oczyszczenia i wzbogacenia o mikroelementy, jest pozyskiwana za pośrednictwem systemu kanałów zlokalizowanych pod miastem (Deep Tunnel Sewerage System, DTSS). Obejmuje on jeden tunel długości 48 km, o średnicy od 3,3 do 6 m, biegnący od Kranji do Changi, dwie rury o długości $5 \mathrm{~km}$, którymi oczyszczona woda trafia do Cieśniny Singapurskiej oraz system kanalizacyjny o długości $60 \mathrm{~km}$. Dziennie jest możliwe uzdatnianie 800 tys. $\mathrm{m}^{3}$ wody. Co ciekawe, $98 \%$ produkowanej wody trafia do przemysłu, pozostała ilość jest poddawana wzbogaceniu, tak aby nadawała się do spożycia. Na obecną chwilę koszty uzyskania tego rodzaju wody są wysokie i dlatego też jej udział w sprzedaży wody butelkowanej jest nikły. Są jednak kontynuowane prace, które pozwolą na obniżenie tych kosztów. Podobnie rzecz się ma z procesem odsalania wody. Pomimo wysokich kosztów inwestycji tego rodzaju przedsięwzięcia są rozwijane. W 2013 r. rodzinna firma Hyflux uruchomiła w Singapurze jeden z największych zakładów odsalania wody na świecie $\left(318,500\right.$ tys. $\mathrm{m}^{3}$ wody dziennie).

Analiza wybranych działań podejmowanych przez władze Singapuru w zakresie gospodarki wodnej pozwala na kilka wniosków. Po pierwsze, woda jest surowcem strategicznym dla tego kraju. To powoduje konieczność dywersyfikacji zasobów. Po drugie, zapewnienie zaspokojenia potrzeb związanych z wodą jest warunkiem koniecznym dla kształtowania jakości życia obywateli i warunków prowadzenia działalności gospodarczej. Po trzecie, inwestycje w ,produkcję wody", systemy odsalania i przeciwpowodziowe opierają się na innowacjach technologicznych, które przynoszą szereg korzyści. Po czwarte, zdobytą wiedzę i doświadczenie Singapurczycy przekazują innym w formie świadczonych usług. Przykładem tego ostatniego jest wybudowanie, przez wspomnianą firmę Heflux, instalacji odsalania wody w Algierii. Jej przepustowość wynosi 500000 tys. m wody dziennie.

\section{Podsumowanie}

Singapur osiągnął sukces na polu gospodarczym dzięki przełamywaniu swoich ograniczeń związanych ze zróżnicowaniem społecznym, niewielkim obszarem terytorialnym, brakiem surowców naturalnych, a także brakiem zasobów wodnych.

Każde działanie podejmowane przez władze było drobiazgowo zaplanowane i uwzględniało lokalne uwarunkowania. Celem tych działań było zapewnienie takich ram rozwojowych, które pozwolą minimalizować ograniczenia 
oraz poszukiwać przewag konkurencyjnych. Przykładem takiego działania jest praktyka Singapuru w zakresie produkcji wody oraz odsalania wody morskiej. Uzyskana w ten sposób wiedza i doświadczenie poparte innowacjami technologicznymi są m.in. przedmiotem usług związanych z doradztwem innym krajom.

Działania związane z pozyskiwaniem zasobów wodnych przyczyniły się do poprawy jakości warunków życia mieszkańców w zakresie infrastruktury sanitarnej, wodnej bazy rekreacyjnej, a także ochrony przeciwpowodziowej.

\section{Bibliografia}

Clifford M.C., The Greening of Asia. The Business Case for Solving Asia's Environmental Emergency, Columbia Business School Publishing, New York 2015.

Ghesquiere H., Singapore's Success. Engineering economic growth, Thomson, Singapore 2007.

Goodman L.K., Mulik K., Clearing the air: Palm Oil, Peat Destruction, and Air Pollution, The Union of Concerned Scientists, 2015, www.ucsusa.org/sites/default/files/attach/2015/03/ clearing-the-air-ucs-2015.pdf (dostęp: 28.06.2016).

Housing and Development Board, http://www.hdb.gov.sg/cs/infoweb/about-us (dostęp: 28.06.2016).

IEA, Singapore: Indicators for 2013, www.iea.org/statistics/statisticssearch/report/?country=Singapore\&product=indicators (dostęp: 25.06.2016).

Land Transport Statistics in brief 2014, www.lta.gov.sg/content/dam/ltaweb/corp/PublicationsResearch/files/FactsandFigures/Statistics\%20in\%20Brief\%202014.pdf (dostęp: 29.06.2016).

Ministry of Education Singapore, Education Statistics Digests 2015, Singapore 2015.

Ministry of the Environment, The Singapore Green Plan 2012. Beyond clean and Green, Towards Environmental Sustainability, Singapore 2002.

Ministry of the Environment and Water Resources, www.mewr.gov.sg/learn-the-issue (dostęp: 25.06.2016).

Ministry of the Environment and Water Resources, Key Environmental Statistics 2015.

Ministry of the Environment and Water Resources, Ministry of National Development, Our Home, Our Environment, Our Future, Sustainable Singapore Blueprint 2015, Singapore 2014.

Monetary Authority of Singapore, Number of Financial Institutions and Relevant Organisations in Singapore, https://masnetsvc.mas.gov.sg/FID.html (dostęp: 26.06.2016).

Neville W., Singapore: ethnic diversity and its implication, „Annals of the Association of American Geographers" 1966, vol. 56, no. 2.

Omar M., Weng Ch.F., British withdrawal from Singapore, singaporeinfopedia, National Library Board Singapore, http://eresources.nlb.gov.sg/infopedia/articles/SIP_1001_2009-02-10.html (dostęp: 27.06.2016).

Singapore: Authorized Institutions, http://asianbanks.net/HTML/Countries/SG/SGauthinst.htm (dostęp: 26.06.2016).

Singapore's Direct Investment Abroad By Country/Region (Stock As At Year End), Annual, www.tablebuilder.singstat.gov.sg/publicfacing/createDataTable.action?refId=5662 (dostęp: 28.06.2016).

Singapore's Direct Investment Abroad By Industry (End Of Period), Annual, Department of Statistics Singapore, www.tablebuilder.singstat.gov.sg/publicfacing/createDataTable.action?refId =5667 (dostęp: 28.06.2016).

Singapore Unemployment Rate 1986-2016, www.tradingeconomics.com/singapore/unemployment-rate (dostęp: 28.06.2016). 
Soon T. Yong, Jean L. Tung, Tan K., Clean, Green and Blue. Singapore's Journey Towards Environmental and Water Sustainability, Institute of Southeast Asian Studies, Singapore 2009.

Szyja P., Rola rozwiazań przyjaznych dla środowiska naturalnego w procesach restrukturyzacji przemystu, Warszawa-Kraków 2014, Prace Komisji Geografii Przemystu Polskiego Towarzystwa Geograficznego, nr 27: Wplyw kryzysu gospodarczego na przemiany struktur przemysłowych.

Targański T., Singapur: fenomenalny 50-latek. Naród z musu, www.polityka.pl/tygodnikpolityka/ historia/1631341,1,singapur-fenomenalny-50-latek.read (dostęp: 26.06.2016).

TOP 50 WORLD CONTAINER PORTS, World Shipping Council, www.worldshipping.org/about-the-industry/global-trade/top-50-world-container-ports (dostęp: 24.06.2016).

Turnbull C.M., A history of modern Singapore 1819-2005, NUS Press Singapore, Singapore 2009.

WESTERN EUROPEAN CITIES TOP QUALITY OF LIVING RANKING-MERCER, London 2016, www.mercer.com/newsroom/western-european-cities-topquality-of-living-ranking-mercer. html (dostęp: 28.06.2016).

World Bank, http://databank.worldbank.org (dostęp: 24.06.2016).

\section{Streszczenie}

W artykule została podjęta kwestia gospodarki wodnej w Singapurze w kontekście rozwoju kraju. Od czasu uzyskania niepodległości władze polityczne kraju dążą do przekształcenia negatywnych skutków lokalnych warunków w sukces. Brak zasobów wodnych stał się przyczynkiem do rozwoju innowacji. Ponadto zdobyta wiedza i doświadczenie pozwalają na świadczenie usług zagranicą w dziedzinie zrównoważonych środowiskowo praktyk.

Słowa kluczowe: gospodarka wodna, woda, rozwój społeczno-gospodarczy, wzrost gospodarczy 